\title{
Constructal Theory: A Tool for Ergonomics
}

\author{
A Heitor Reis* \\ Department of Physics and Institute of Earth Sciences (ICT), University of Évora, R. Romao Ramalho, Evora, Portugal
}

*Corresponding author: A Heitor Reis, Department of Physics and Institute of Earth Sciences (ICT), University of Évora, R. Romao Ramalho, 59, $7002-554$ Evora, Portugal, Tel: 351 967324948; E-mail: ahr@uevora.pt

Received date: July 20, 2015; Accepted date: July 23, 2015; Published date: August 1, 2015

Copyright: $\odot 2015$ Reis HA. This is an open-access article distributed under the terms of the Creative Commons Attribution License, which permits unrestricted use, distribution, and reproduction in any medium, provided the original author and source are credited.

\section{Introduction}

Constructal theory proposes to see living bodies as machines that are subjected to constraints, which are constructed with a goal, an objective, which is to obtain maximum efficiency. The Constructal Law states that if a system has freedom to morph it develops in time the flow architecture that provides easier access to the currents that flow through it [1]. Here, the term "flow" means everything that invades a territory, such that in a living territory as it is the human body it encompasses flows of heat, electricity and biologic fluids, and also flow of mechanical stresses [1-4].

The Constructal Law is as general as the First and Second Laws of Thermodynamics but has a very different scope that makes it unique and complementary to those laws. While the First Law points to conservation of energy, both the Constructal Law and the Second Law point to change, i.e. to a direction in time. Though the last two laws share this common feature, they diverge as with respects to scope. Contrarily to the Second Law, Constructal Law applies to systems out of equilibrium, i.e., systems that evolve in time. While the Second Law deals with state variables, the Constructal law combines flows and design (size, shape, structure) [2-5].

\section{Applications to living systems}

In early works Bejan [1] has addressed the rhythm of respiration in animals in relation with the body size and found that breathing time increases with the animal body size rose to the power $1 / 4$, which is in good agreement with the biological observations. In the same way, the optimal heart rate is approximately proportional to the square of the metabolic rate [1]. Related to this is the proportionality between body heat loss and body size raised to the power $3 / 4[1,6]$. As another example, for optimal performance, the cruising speeds of flying structures must be proportional to the $1 / 6$ power of their body mass $[1,7]$. Additional constructal predictions of alometric laws can be found in the references [1-4].

Murray's Law that states that the "cube of the radius of a parent vessel equals the sum of the cubes of the radii of the daughters" [8] stays as a landmark scaling law of geometries of branching channels with non-turbulent flows. Bejan et al. [9] proved that Murray's law may be deduced from the Constructal Law, and recently Silva and Reis [10] extended Murray's law for pulsatile flows, namely blood flow in arteries. These authors also explained why optimal performance of the arterial tree requires reduction of arterial distensibility with increasing heart rate [11].

Reis and co-workers also showed that the best oxygen access to the tissues is performed by a flow structure composed of ducts with 23 levels of bifurcation. The same structure has been shown to be optimized for carbon dioxide removal as well. This explains why the human lung tree has 23 levels of branching [12].

Based on the Constructal Law, Bejan and Marden showed that animal movement (running, flying, swimming) and fluid eddy movement (turbulent structure) are both forms of optimized intermittent movement [13]. Charles and Bejan [14] also explained why the fastest runners and swimmers are becoming not only faster but also heavier, taller and more slender, while Bejan et al. [15] anticipated that "the trends in four sports are united by the evolutionary constructal design of all animal locomotion. The trend is toward greater efficiency in the falling-forward movement of the body, and this is why the evolution of the throwing motion unites team sports (baseball, hockey) with individual sports (golf, boxing, running and swimming). "Lorente et al. [16] showed that "swimming animals and athletes gain an advantage in force and speed by spreading their fingers and toes optimally. The larger force means larger body mass lifted and greater speed, in accord with the Constructal Theory of all animal locomotion. The spacing between fingers must be twice the thickness of the boundary layer around one finger."

These are some examples of a growing body of works with successful applications of the Constructal Law to living systems. For more details please see the reviews [1-4].

\section{Conclusions}

Constructal Theory provides a methodology based on the Constructal Law that showed to be useful for studying important features of living systems. It unifies both the mechanics and thermodynamics perspectives on such systems to provide a new paradigm of analysis. As a result, many aspects, namely shape and structure of living systems may be explained, while trends of evolution may be anticipated. The purpose of this Editorial was just to call the attention of those involved in the study of complex systems - such as the human body - for Constructal Theory as a new research tool.

\section{References}

1. Bejan A (2000) Shape and Structure: From Engineering to Nature. Cambridge: Cambridge University Press.

2. Reis AH (2006) Constructal theory: From engineering to physics, and how flow systems develop shape and structure. Appl Mech Rev 59: 269-282.

3. Bejan A, Lorente S (2008) Design with Constructal Theory. Wiley, Hoboken.

4. Bejan A, Zane JP (2012) Design in Nature: How the Constructal Law Governs Evolution in Biology, Physics, Technology, and Social Organization. Doubleday.

5. Reis AH (2014) Use and validity of principles of extremum of entropy production in the study of complex systems. Annals of Physics 346: 22-27. 
6. Bejan A (2001) The Tree of Convective Heat Streams: Its Thermal Insulation Function and the Predicted 3/4-Power Relation between Body Heat Loss and Body Size. Int J Heat and Mass Transfer 44: 699-704.

7. Bejan A (2002) Constructal Theory of Organization in Nature: Dendritic Flows, Allometric Laws and Flight. Design and Nature, C. A. Brebbia, L. Sucharov and P. Pascolo, Eds., WIT Press, Southampton, UK, pp. 57-66.

8. Murray CD (1926) The Physiological Principle of Minimum Work: II Oxygen Exchange in Capillaries, Proc. of the National Academy of Sciences of the United States of America 12: 299-304.

9. Bejan A, Rocha LAO, Lorente S (2000) Thermodynamic optimization of geometry: T- and Y-shaped constructs of fluid streams. Int $\mathrm{J}$ Thermal Sciences 39: 949-960.

10. Silva C, Reis AH (2014) Scaling relations of branching pulsatile flows. Int J of Thermal Sciences $88: 77-83$.
11. Silva C, Reis AH (2014) Heart rate, arterial distensibility and optimal performance of the arterial tree. J of Biomechanics 47: 2878-2882.

12. Reis AH, Miguel AF, Aydin M (2004) Constructal theory of flow architecture of the lungs. Medical Physics 31: 1135-1140.

13. Bejan A, Marden JH, (2006) Unifying Constructal theory for scale effects in running, swimming and flying. J Experimental Biology 209: 238-248.

14. Charles JD, Bejan A (2009)The evolution of speed, size and shape in modern athletics. J Experimental Biology 212: 2419-2425.

15. Bejan A, Lorente S, Royce J, Faurie D, Parran T, et al. (2012) The constructal evolution of sports with throwing motion: Baseball, golf, hockey and boxing. Int J of Design and Nature and Ecodynamics 8: 1-16.

16. Lorente S, Cetkin E, Bello-Ochende T, Meyer JP, Bejan A (2012) The constructal-law physics of why swimmers must spread their fingers and toes. J Theoretical Biology 308: 141-146. 